\section{Marketing Communications of Higher Education Institutions in the Republic of Serbia}

\author{
Ana Popović
}

Abstract: In order to face increasing competition on the market and address other new challenges, higher education institutions (HEls) started to apply new business approaches which led to the development of higher education management and marketing. As efficient marketing communications are necessary for survival and development on higher education market, topics related to this field have had a distinct place in higher education marketing since the establishment of this discipline. Various strategies and activities, types and means of marketing communications have been defined in theory. The modern tendency is their integration for achievement of communication and strategic goals.

After the review of marketing communications specifics in the mentioned context, the author presents the realized empirical research related to HEls in the Republic of Serbia. Starting from the facts that domestic higher education market has widened relatively recently and competition has been significantly increasing since 2000 , the author hypothesizes that numerous marketing communications activities are being used. The main research question is: Which types and means of marketing communications are used and how well are they integrated? The research relies on web sites of HEls as main sources of information, as they are legally obligatory means of communication in Serbia. The author searches for other types and means which are embedded or at least mentioned on the websites, and treats that as indication of integration.

The main research findings support the assumption on use of various types and means of marketing communications, but reveal problems in integration and show that HEls use similar activities while innovative and original means and types of marketing communications are scarce.

Key words: higher education institutions, marketing communications, competition, competitive advantage, integrated marketing communications, higher education marketing 
and then theoretically conceptualized. Today, scope of research of higher education marketing is defined as "marketing principles and activities (originally developed in profit, business context -author's note) adopted and applied in higher education institutions" (Kotler, 1979, p.40), primarily with aim to develop competitive advantage and increase market share in national and international market.

Marketing communications activities take distinct place among the marketing activities applied in higher education institutions. They are the subject matter of this study. After the short theoretical background about marketing communications in the sector of higher education, author presents analysis of marketing communication types and means deployed by higher education institutions in the Republic of Serbia. The findings presented in this paper derive from empirical desk research, more precisely analysis of secondary research data sources. The content of Internet presentations (websites) of all accredited higher education institutions (HEIs) in Republic of Serbia was analyzed in order to determine which types and means of marketing communications are presented and how well they are integrated. The assumption is that all used types and means of marketing communications should be embedded or at least mentioned on the web sites which are obligatory for HEIs in Serbia. After presentation of research subject, research sample, methodology, findings and discussion, author presents limitations, directions for further research and implications for marketing researchers and practitioners.

Theoretical background: Marketing communications of higher education institutions

In the early phases of its development in practice, higher education marketing was almost exclusively related to application of marketing communications activities in this sector. More precisely, higher education marketing was dealing with possibilities for application of:

$$
\begin{aligned}
& \text { persuasive advertising and personal selling } \\
& \text { (through direct contact with potential students) as } \\
& \text { types of marketing communications, } \\
& \text { posters, brochures, printed notifications etc. as } \\
& \text { means of marketing communications, or, rath- } \\
& \text { er - advertising, in higher education institutions } \\
& \text { (according to: Hemsley-Brown \& Oplatka, 2006). }
\end{aligned}
$$

Accordingly, the development of higher education marketing theory started with publication of first manuals related to possibilities for application of various types and means of marketing communications in higher education institutions (see: e.g. Kotler \& Fox,
1985, Davies \& Scribbins, 1985; Keen \& Warner, 1989, Gibbs \& Knapp, 2001). And even though higher education marketing has been constantly evolving, including more and more activities and developing towards comprehensive, strategic approach, marketing communications remained one of the main fields of research in this discipline (Stanković \& Popović, 2014, p.524). Contemporary higher education marketing recognizes all types and means which are traditionally present in "mainstream"1 marketing (see, e.g. Kotler \& Keller, 2006; Stanković \& Đukić, 2014, p.51):

both direct (i.e. personal selling and direct marketing) and indirect types (i.e. advertising, sales promotion, public relations and publicity, special events, Internet marketing), as well as print (e.g. newspapers, magazines, brochures, etc.), electronic (radio, television and Internet) and other (e.g. billboards) means of marketing communications.

As in mainstream marketing, the tendency in higher education marketing is towards developing integrated marketing communications (see: Edmiston, 2008; Schüller \& Rašticová, 2011) including integration of all types and all means of marketing communications in order to achieve desired outcomes (Schultz, 2010), in this case to consistently and coherently transfer the messages to all the relevant groups of higher education institution's public and to ensure their feedback.

In defining and implementing marketing communications activities in higher education institutions, common starting point is the understanding that students are not passive but active, i.e. rational and well informed (Niculescu, 2009) clients expected to make decisions by choosing appropriate educational programme at institutions that provide high quality of education (Baldwin \& James, 2000; Grubor, 2012). This becomes clear bearing in mind how choice of educational programme influences profession, career path and future of an individual. Another related specific of higher education is the fact that majority of students take a role of a client only once (vast majority of them are students on an institution only once ${ }^{2}$ ),

\footnotetext{
${ }^{1}$ Marketing as originally developed, related to profit institutions of business, commercial sector (see, e.g. Popović, 2010).

${ }^{2}$ Exception can be found in potential cases when students study more than one programme at the same higher education institution (on the same educational level, eg. two master courses; or on sucessive levels - BSc, MSc and PhD programmes). But even then, students are HEI's clients during definite period, while individuals can be clients of companies for longer periods or even be loyal to a brand or organization their whole lifetime.
} 
while in business sector purchases and uses of most of the products and services often repeat (individuals or organizations can take a role of consumers or customers of a company numerous times and develop loyalty) (Temple \& Shattock, 2007). Mentioned specifics determine behaviour of students as users of higher education services, and influence creating and implementing marketing strategies in higher education sector. Namely, selection of higher education institution and programme represents a type of purchase characterized by intensive engagement of consumer or client - in this context - prospective student. In these situations, clients highly value and take into consideration information provided through marketing communications activities (see: e.g. Stanković \& Đukić, 2014, p.131). Therefore, it is of tremendous importance to provide relevant and credible information that enable prospective students to make the appropriate decision. Lack of adequate information that reflect actual characteristics of higher education institution and programme, leads to higher risk of wrong choice which is especially problematic for international students (Mortimer, 1997). Namely, because of higher education specifics, in most cases prospective students cannot easily "fix" the wrong choice by simply choosing another institution or programme, as they can often do in commercial sector by exchanging unsatisfactory product or service or simply buying a new one. In higher education sector, costs of transferring to another programme or institution are very high and, in addition to monetary expenses include time - delay, postponing, waiting (e.g. for the start of next academic year) and psychological effort related to additional engagement in new round of gathering and analyzing information, decision making related to new option and preparing for enrolment to other programme/institution.

Keeping in mind all the delicate issues related to this area, numerous studies have been realised with aim to define guidelines for appropriate marketing communications strategies and activities for higher education institutions (e.g. Mortimer, 1997; Gatfield et al., 1999; Hesketh \& Knight, 1999). The common conclusion is that marketing communications of higher education institutions need to be based on strategic approach and results of systematic marketing research aimed at discovering informational needs and preferences of prospective students. The final aim is to provide students with sufficient and relevant information about characteristics of institution, necessary for decision making (see e.g. Mortimer, 1997; Bakewell \& Gibson-Sweet, 1998; Sander et al., 2000;
Ivy, 2001; Oplatka, 2002; Maringe, 2005). Information need to be accurate, as inappropriate experiences of prospective students related to insufficient and deceptive information provided, can have very negative influence on image and reputation of higher education institution (Stanković \& Popović, 2014, p.526).

Starting from these considerations, the basis of empirical research presented below is defined. The principal research question is formulated as follows:

- Which types and means of marketing communications are used in practice of higher education institutions in Serbia?

Additional research questions pertain to specific types and means of communications implemented in higher education institutions in Serbia:

1. To what extent are these types and means integrated?

2. Are there any types and means of marketing communications which are theoretically conceptualized but not used (sufficiently) in the practice of higher education institutions in Serbia?

\section{RESEARCH OF THE MARKETING COMMUNICATIONS OF HIGHER EDUCATION INSTITUTIONS IN REPUBLIC OF SERBIA}

\section{Research Description}

The subject, objectives and scope of the research. The subject of this research includes types and means of marketing communications used by higher education institutions in the Republic of Serbia, directed to potential students and the general public.

The principal objective of the research is to determine the types and means of marketing communications used by higher education institutions in the Republic of Serbia.

The additional research objectives are the following:

1. Identifying the level of integration of the used types and means of marketing communications;

2. Highlighting the types and means of marketing communications that are theoretically conceptualized, but are not (sufficiently) used in the practice of higher education institutions in the Republic of Serbia. 
The scope of the research includes all accredited ${ }^{3}$ higher education institutions $s^{4}$ in the Republic of Serbia, including:

1) faculties - in the cases when they have status of legal entities, and

2) integrated universities, in the cases when their constituent faculties do not have the status of independent legal entities.

The preliminary list of accredited higher education institutions is defined on the basis of:

1. List of accredited faculties and universities set by the Commission for Accreditation and Quality Assurance of the Ministry of Education, Science and Technological Development of the Republic of Serbia (Odbor za akreditaciju naučno-istraživačkih organizacija, 2014), and

2. Official information presented on the websites of accredited Serbian universities about the faculties within those universities.

The preliminary list of accredited higher education institutions was then redefined in accordance with the most recent Guide through Accredited Study Programs in the Institutions of Higher Education in Serbia (Komisija za akreditaciju i proveru kvaliteta, 2015). The final number of accredited higher education institutions with the status of legal entities is 131, of which 87 institutions are founded by the Republic of Serbia (so-called "state(-founded)" or "public" universities and faculties) and 54 are not founded by the Republic, but private subjects (so-called "private" universities and faculties) $)^{5}$. These 131 institutions constitute research population.

\footnotetext{
${ }^{3}$ Higher education institutions where teaching is carried out within accredited study programmes (at least one programme is accredited).

${ }^{4}$ The research is done on the level of institutions (either faculties or integrated universities) and not individual departments or study programs, as marketing communications strategies and means (e.g. brochures, presentations on social networks, videos, presentations in secondary schools, education fairs, and the like) are in vast majority of cases (126 out of 131) designed and implemented for the level of entire institution (see: Popović, Stanković \& Đukić, 2015).

${ }^{5}$ Out of the institutions founded by the Republic, the analysis was done on the level of faculties in 86 cases (as all the facultires from state-founded Universities of Belgrade, Niš, Kragujevac, Novi Sad and Priština are accredited and have status of elgal entities) and on the level of the university in only 1 case, as State University of Novi Pazar is the only integrated state-founded university (it does not consist of faculties as separate legal entities, but departments which are completely dependent -integrated).
}

Sources and methods of data collection. In order to identify the types and means of marketing communications used by higher education institutions in the Republic of Serbia and level of their integration, the author analyzed the content of websites for several reasons.

Firstly, websites are only obligatory means of marketing communications for higher education institutions in the Republic of Serbia. These institutions are legally obliged to communicate with interested groups through their websites ${ }^{6}$. All institutions of designated population do have websites and update their content fairly regularly ${ }^{7}$.

Secondly, the direct analysis of other types and means of marketing communications (instead of the websites) would cause significant limitations. "The vast majority of higher education institutions in the Republic of Serbia are not promoted in the mass media, and even when they are, they are advertised on local television and radio stations and in local printed media, which makes it difficult for researchers to analyze their messages. The same applies to the potential analysis of other media with limited range (e.g. billboards). Dissemination of printed promotional materials (information leaflets, booklets, brochures, etc.) is generally performed at special (local or regional author's note) events ("Open Doors Days", education fairs, presentations of higher education institutions to secondary school students, etc.). " (Popović, Stanković \& Đukić, 2015, pp. 650-651)

Additionally, assumption is that if other types and means of marketing communications are used by higher education institutions, they should be presented on their web sites. Namely, most of the promotional means "exist in digital form on the websites of higher education institutions, which is an additional argument for (...), decision to analyze the content of Internet presentations." (ibid, p. 651).

\footnotetext{
Out of the institutions fouded by privare subjects, the following cases are excluded from the population: the higher education institutions that belong to the accredited "private" universities but are not accredited themselves, or are in the process of accreditation, or do not have the status of a legal entity.

${ }^{6}$ See, e.g. the Rules of standards for self-evaluation and quality assessment of higher education institutions - Standard 14 - Annex 1 (Национални савет за високо образовање, 2006).

${ }^{7}$ Out of all analysed institutions, 108 have their own websites, while 23 are presented on separate pages within the websites of the universities to which they belong (three faculties of the Megatrend University, two faculties of the Alfa University, all three faculties of the Metropolitan University, six faculties of the Singidunum University, and nine faculties of the Educons University).
} 
Therefore, the analysis is directed towards types and means which are embedded or at least mentioned on the websites, which is then treated as indication of integration of marketing communications. This approach can be considered for a certain limitation of the research - institutions could be using other means and types of marketing communications, but not mentioning them on their websites. Still, that would also mean that marketing communications are not appropriately integrated, and that issue is in the focus of this research.

The information about used types and means were searched for on several locations on the websites:

1. Home/main page - the assumption was that information about some communication types and means would be indicated on this page, e.g. Internet marketing communications - links to institution's profile on social networks (facebook, Twitter, Youtube, LinkedIn, etc.) and the like,

2. Web pages that are related to the call for enrolment in the first year of study at a specific faculty/university - the assumption was that some communication types and means would be indicated on these pages, e.g. electronic version of promotional leaflet, booklet, promotional video and similar means of advertising or information about special benefits for prospective students - which would be a pendant for sales promotion as used in business sector;

3. Web pages with news related to the institution's activities - the assumption was that some communication types would be indicated on these pages, e.g. information about organizing (e.g. Open doors day) or taking part in special events (e.g. Education fairs); or about presentations in targeted high schools - which would be treated as pendant to personal selling as a type of marketing communications;

4. Web pages with media coverage or press releases/ clipping about the institution (e.g. "Our institution in media", or "Media about us", etc.) - these pages provide direct indications about publicity as a type of marketing communications;

5. Web pages with contact information or information on organizational structure - these pages were analysed in order to get direct information about existence of person/team/office or service directly involved in public relations as a type of marketing communications.

Research period. Data collection for research purposes began in early January 2015 and lasted until
mid-May 2015. The desk research was realized in this period assuming that the data about the call for admission to the first year of studies (for the academic year 2015/16) would be placed on the websites of higher education institutions during that time, as the enrolment begins in June in most institutions. This created the necessary basis for the research of types and means of marketing communications, as they should be in their full use in this period when the communication directed to prospective students is the most intensive.

\section{Analysis of Research Results}

The data obtained through empirical desk research should provide the basis for answering the principal research question: Which types and means of marketing communications are used in practice of higher education institutions in Serbia? Since the main objective of the research is descriptive, research results are presented by use of methods of descriptive statistics. Since the research relates to the entire population of accredited higher education institutions in the Republic of Serbia (and not the chosen sample), there is no need to apply inferential statistics and statistical tests in this paper.

Marketing communications on websites of higher education institutions in the Republic of Serbia. In the period the research was conducted, the vast majority of accredited higher education institutions in the Republic of Serbia (121 institutions or 92\%) displayed explicitly on their websites information related to call for enrolment of prospective students, which created an appropriate discourse for analysis of marketing communications messages. Nearly half of the institutions (61 of them or 47\%) implicitly displayed promotional appeals directed towards prospective students and general public, stating competitive advantages that make them distinct and different from competing institutions (more in: Popović et al., 2015).

After a detailed preliminary analysis of the content of websites of all the analyzed higher education institutions, it was concluded that all the theoretically conceptualized types of marketing communications are used in practice of these institutions. The marketing communication types were classified into eight categories and it was found that the most frequently used types were Internet marketing communications, while the rarest were direct types of marketing communications - direct marketing and personal selling. A more detailed review is presented in Table 1. 
TABLE 1. Types of marketing communications used by higher education institutions in the Republic of Serbia (descending frequency)

\begin{tabular}{|l|c|c|}
\hline $\begin{array}{l}\text { Marketing } \\
\text { communications type }\end{array}$ & $\begin{array}{c}\text { No. of HEls } \\
\text { using it }\end{array}$ & $\begin{array}{c}\% \text { of total } \\
\text { population }\end{array}$ \\
\hline $\begin{array}{l}\text { Internet marketing } \\
\text { - web sites } \\
\text { - other means }\end{array}$ & 131 & $100 \%$ \\
\hline Advertising & 104 & $79 \%$ \\
\hline $\begin{array}{l}\text { Special events } \\
\text { - participation }\end{array}$ & 86 & $66 \%$ \\
\hline - organization & 39 & $30 \%$ \\
\hline Sales promotion & 33 & $25 \%$ \\
\hline Public Relations & 33 & $25 \%$ \\
\hline Publicity & 17 & $13 \%$ \\
\hline Personal selling & 10 & $8 \%$ \\
\hline Direct marketing & 2 & $1,5 \%$ \\
\hline
\end{tabular}

The details related to detected types of marketing communications are discussed in the further text.

Internet marketing communications of higher education institutions in the Republic of Serbia. Internet marketing communications were analyzed separately, even though they can be considered for a type of advertising, if Internet is just perceived as means of advertising. However, in this study, Internet marketing is perceived as a separate type that includes marketing communications via various means of communications, as on-line social networks, blogs, forums etc. (see, e.g. Stanković \& Đukić, 2014). Being obligatory, web site is used as a means of Internet marketing communications by all instuitions from the investigated population. Distribution of other means of Internet communications is presented in the table 2.

TABLE 2. Means of Internet marketing communications used by higher education institutions in the Republic of Serbia (descending frequency)

\begin{tabular}{|l|c|c|}
\hline $\begin{array}{l}\text { Marketing } \\
\text { communications type }\end{array}$ & $\begin{array}{c}\text { No. of HEls } \\
\text { using it }\end{array}$ & $\begin{array}{c}\text { \% of total } \\
\text { population }\end{array}$ \\
\hline facebook & 79 & $60 \%$ \\
\hline YouTube & 48 & $37 \%$ \\
\hline twitter & 41 & $31 \%$ \\
\hline Google+ & 14 & $11 \%$ \\
\hline blogs & 7 & $5,5 \%$ \\
\hline forums & 5 & $4 \%$ \\
\hline
\end{tabular}

Other means of Internet marketing communications, used by HEIs in Serbia (with frequency less than 5) were: flickr, SoundCloud, Vimeo, LinkedIn, Instagram.

These findings should be understood only as preliminary indications, as the analysis pertains to forms and means of Internet marketing communications directly and implicitly presented on the institutions websites. However, additional analysis revealed that 14 additional institutions have profiles on facebook, 1 on YouTube and 1 on twitter. But, these profiles were not mentioned nor indicated (by logos, pictograms or links) on institutions' websites which shows poor level of integration of marketing communications.

Another additional analysis was performed in order to check if there is a difference regarding use of Internet marketing communications by HEIs of different types ${ }^{8}$. The detailed review is presented in the table 3.

TABLE 3. Use of Internet marketing communications by different types of HEls

\begin{tabular}{|c|c|c|c|c|c|c|c|}
\hline \multicolumn{7}{|c|}{ Type of HEl according to } \\
\hline \multicolumn{2}{|c|}{ Founder } & \multicolumn{5}{c|}{ Field of studies } \\
\hline $\begin{array}{c}\text { State- } \\
\text { founded }\end{array}$ & Private & $\begin{array}{c}\text { 1. } \\
\text { HS }\end{array}$ & $\begin{array}{c}\mathbf{2} \\
\text { NM }\end{array}$ & $\mathbf{3 .}$ & $\mathbf{4}$ & $\mathbf{4}$ & $\mathbf{5}$ \\
M & A* \\
\hline No. & 74 & 30 & 52 & 11 & 23 & 9 & 9 \\
\hline$\%$ & $85 \%$ & $55,5 \%$ & $87 \%$ & $92 \%$ & $68 \%$ & $82 \%$ & $75 \%$ \\
\hline
\end{tabular}

HS -humanities and social sciences, NM - sciences (natural and mathematics), TT - technical and technological, M- medicine, A - arts

Additionally, it was noted that eight "private" faculties from the field of hunanities presented information about use of means of mobile marketing - 3 mobile applications (registered on google apps) developed for updating students about news related to their study programmes.

Advertising as a type of marketing communications is, according to the data presented on websites, used by $86(66 \%)$ higher education institutions in the Republic of Serbia. Means of advertising used by these HEIs, or more precisely - frequency of use of these means is shown in the table 4 .

\footnotetext{
${ }^{8}$ Higher education institutions were classified according to teo amin criteria: 1 . criterion related to institiution's founder, 2. criterion related to field of studies (see: Zakon o visokom obrazovanju, 2013).
} 
TABLE 4. Means of advertising used by higher education institutions in the Republic of Serbia (descending frequency)

\begin{tabular}{|l|c|c|} 
Means of advertising & $\begin{array}{c}\text { No. of HEls } \\
\text { using it }\end{array}$ & $\begin{array}{c}\text { \% of total } \\
\text { population }\end{array}$ \\
\hline Promotional video & 44 & $34 \%$ \\
\hline Brochures & 23 & $18 \%$ \\
\hline Leaflets & 3 & $2 \%$ \\
\hline
\end{tabular}

These findings should also be cautiously interpret,ed as they are related only to means presented on the websites. Only videos with content which can be considered for promotional were taken into account (e.g. videos with stories of successful alumni or students, stories about institution or courses, virtual tours through institution, etc. with clear message inviting new prospective students) and only electronic version of traditional print promotional materials as brochures (with information for prospective students) or leaflets (usually for presentation of individual study programme). Only two cases of advertising via mass media were uploaded on the website - one promotional video broadcasted on local television and one article advertising course for preparing prospective students for entrance examination. However, additional analysis revealed 5 more cases of promotional videos on YouTube, which were not presented on institutions' websites, dozen cases of advertising on television, in newspapers and magazines and via billboards. The fact that these were not presented on the institutions ' websites, shows again poor level of integration of marketing communications.

Results of additional analysis related to the use of advertising by HEIs of different types are shown in the table 5 .

TABLE 5. Use of advertising by different types of HEls

\begin{tabular}{|c|c|c|c|c|c|c|c|}
\hline & \multicolumn{7}{|c|}{ Type of HEl according to } \\
\hline & \multicolumn{2}{|c|}{ Founder } & \multicolumn{5}{|c|}{ Field of studies } \\
\hline & $\begin{array}{l}\text { State- } \\
\text { founded }\end{array}$ & Private & $\begin{array}{l}1 . \\
\text { HS }\end{array}$ & $\begin{array}{c}2 . \\
\text { NM }\end{array}$ & $\begin{array}{l}3 . \\
\pi\end{array}$ & $\begin{array}{l}4 . \\
\text { M }\end{array}$ & $\begin{array}{r}5 . \\
A^{*}\end{array}$ \\
\hline & 50 & 37 & 58 & 7 & 12 & 4 & 6 \\
\hline 0 & $68 \%$ & $68 \%$ & $97 \%$ & $66 \%$ & $35 \%$ & $36 \%$ & $50 \%$ \\
\hline
\end{tabular}

Special events as types of marketing communications of higher education institutions in the Republic of Serbia were analysed on two levels - events organized by the institution (used by 33 institutions or 25\%) and events in which institution takes part (used by 39 institutions or $30 \%)$. The typical example of the first type of events, organized by institutions, is so-called "Open Doors Day" which is usually organized once in the semester that precedes the Call for enrolment for the new prospective students. In four cases, institutions organize Open Doors Day once a week in the longer period before enrolment (in two cases in the period from November-June and from March-June and in two cases once a week throughout a whole year). Open Doors Day represents a promotional activity and an event when prospective students (sometimes their parents - explicitly mentioned in 4 cases; or their teachers - explicitly mentioned in 2 cases) can visit the institution, see how it looks like and operates and get information about study programmes etc.

The typical example of the second type of events, which higher education institutions take part in, are so-called "education fairs". Prospective students and other interested parties are invited by organizers to visit these events where various higher education institutions are presented and where all the interested visitors can get information and promotional materials and see presentations of those institutions.

The author analysed which of these events are mentioned and presented on the web sites of the institutions - whether the organization or involvement in special events is announced or reported about on the websites. The results of this analysis related to HEIs of different types are shown in the table 6 .

There is a possibility that more HEIs organize or take part in more special events then number of these events presented on the websites. Lack of announcements and news about these events on websites is very problematic, as timely upload of news is also an invitation for all the potential visitors.

Sales promotion represents a very specific type of marketing communications in the context of higher education institutions in the Republic of Serbia. Namely, in the context of profit, business organizations, sales promotions rely on specific means (e.g. free samples, presents etc.) or activities (special offer/ sale, degustation, presentation, and lottery) aimed at increasing sales. As higher education institutions are not involved in sales as much as business organizations ${ }^{9}$, it was expected that this type of marketing communications would be relatively rare. And indeed, only $25 \%$ of the higher education institutions

\footnotetext{
${ }^{9}$ Pendant to „sales“ exists on private HEIs which charge studies from students (except from some who receive scholarships or study "for free“ as the best students in the generation) and partly in case of students who pay tuition fees on state-founded HEIs.
} 
TABLE 6. Special events as means on marketing communications of different types of HEls

\begin{tabular}{|c|c|c|c|c|c|c|c|c|}
\hline & & \multicolumn{7}{|c|}{ Type of HEl according to } \\
\hline & & \multicolumn{2}{|c|}{ Founder } & \multicolumn{5}{|c|}{ Field of studies } \\
\hline & & $\begin{array}{c}\text { State- } \\
\text { founded }\end{array}$ & Private & 1. HS & 2. NM & 3. $\pi$ & 4. $M$ & 5. $A^{*}$ \\
\hline \multirow{2}{*}{ Events organized by HEI } & No. & 21 & 12 & 22 & 3 & 7 & 1 & 0 \\
\hline & $\%$ & $24 \%$ & $22 \%$ & $36 \%$ & $25 \%$ & $21 \%$ & $9 \%$ & / \\
\hline \multirow{2}{*}{ Events in which HEI takes place } & No. & 24 & 15 & 20 & 3 & 12 & 3 & 1 \\
\hline & $\%$ & $28 \%$ & $28 \%$ & $33 \%$ & $25 \%$ & $35 \%$ & $25 \%$ & $8 \%$ \\
\hline
\end{tabular}

(33 of 131) use some type of sales promotions. And of course, $85 \%$ of the institutions that use it, are private HEIs, as the vast majority of their students are paying tuition fees and those fees are the main sources of financing these institutions. Public HEIs in Serbia are supported by the Republic, so significant number of students on these institutions does not pay for studies and are financed by the state. Public institutions are less dependent on "sales" so, logically, sales promotion is rarely used by them. Typical examples of sales promotion in this context include:

- benefits related to tuition fees (e.g. "the lowest fees in the country", "prices unchanged for years", " $20 \%$ off for the early bird applications for enrolment", " ( $1^{\text {st }}$ year of $)$ studies free of charge/ scholarships for the best candidates", possibilities for paying in instalments, financial support for students with fewer opportunities, etc.); special benefits ( free of charge: course/consultations for preparation of entrance examination, (on-line) application for entrance examination; "presents" - promotional brochures and other materials, textbooks and books, lectures recorded on CDs or USB flash memories; discount prices for professional books, courses, licences, public transport, etc.)

Use of this means of communication on public and private HEIs and HEIs from different fields of studies is presented in the table 7 .

TABLE 7. Use of sales promotion by different types of HEIS

\begin{tabular}{|c|c|c|c|c|c|c|c|}
\hline & \multicolumn{7}{|c|}{ Type of HEl according to } \\
\hline & \multicolumn{2}{|c|}{ Founder } & \multicolumn{5}{|c|}{ Field of studies } \\
\hline & $\begin{array}{c}\text { State- } \\
\text { founded }\end{array}$ & Private & $\begin{array}{l}1 . \\
\text { HS }\end{array}$ & $\begin{array}{c}2 . \\
\text { NM }\end{array}$ & $\begin{array}{l}3 . \\
\pi\end{array}$ & $\begin{array}{l}4 . \\
\text { M }\end{array}$ & $\begin{array}{l}5 . \\
A^{*}\end{array}$ \\
\hline No. & 5 & 28 & 22 & 2 & 6 & 1 & 2 \\
\hline$\%$ & $6 \%$ & $52 \%$ & $37 \%$ & $17 \%$ & $18 \%$ & $9 \%$ & $17 \%$ \\
\hline
\end{tabular}

Public relations (PR) and publicity turned up to be types of marketing communications rarely used by higher education institutions in the Republic of Serbia. Only 17 HEIs (13\% of population) use PR, and even less - 10 of them (8\%) use publicity. The approach used in analysing public relations as a type of marketing communications of HEIs is related to organization of PR activities. Namely, the only cases which were taken into account are those in which on the websites of HEIs it was explicitly mentioned that public relations are done by a person ( 9 or $53 \%$ of cases), special sector/service/office (7 or $41 \%$ ) or a team ( 1 or $6 \%)$ designated for related activities. Also, the cases considered for the use of publicity were only those where on the websites, institutions had uploaded media reports (independent journalists' reports on institution, organized events, enrolment etc.; interviews with professors on TV or in newspapers etc.). Therefore, the data presented in table 8 should be cautiously interpreted, and understood only in mentioned terms. Namely, the presented data only undoubtedly support the fact that marketing communications of HEIs are not well integrated. Highly possibly higher education institutions in Serbia use public relations as means of marketing communications more, but:

- those activities are integrated, by official classification, in some other work places/services/offices which names do not include indicators as "PR", "marketing", "communications",or, people/services working in PR are just not presented on websites ${ }^{10}$.

Also, HEIs might have publicity, but media reports might not be monitored, recorded or uploaded to websites.

\footnotetext{
${ }^{10}$ E.g. in four cases, PR is done within Office for marketing and $P R$. The most developed case is one with a director and $6 \mathrm{em}-$ ployees.
} 
TABLE 8. Use of PR and publicity by different types of HEIS

\begin{tabular}{|l|c|c|c|c|c|c|c|c|}
\hline \multirow{2}{*}{} & \multicolumn{8}{|c|}{ Type of HEl according to } \\
\cline { 2 - 11 } & \multicolumn{3}{|c|}{ Founder } & \multicolumn{4}{c|}{ Field of studies } \\
\cline { 2 - 11 } & State-founded & Private & 1. HS & 2. NM & 3. T & 4. M & 5. A* \\
\hline \multirow{2}{*}{ PR } & 11 & 6 & 7 & 2 & 5 & 0 & 3 \\
\hline \multirow{2}{*}{ Publicity } & No. & $13 \%$ & $11 \%$ & $12 \%$ & $17 \%$ & $15 \%$ & $/$ & $25 \%$ \\
\hline & $\%$ & 9 & 3 & 9 & 1 & 1 & 0 & 1 \\
\hline
\end{tabular}

Direct types of marketing communications - pendants to Personal selling and direct marketing in business sector - are the rarest in the practice of higher education institutions in the Republic of Serbia. Both are found in only 2 explicit cases. Discovered pendants to personal selling are:

- presentations of HEIs in targeted secondary schools (from which the large inflow of prospective students is expected) - presented on the website of only one institution from the population; workshop for secondary school pupils - prospective students ("Be our student for a day")- presented on the website of one institution from the population.

Discovered pendants to direct marketing activities are related to possibilities for interactive communication and exchange on two websites:

- in one case, prospective and actual students can insert contact details and receive regular updates about their study programme,

- in the second case, prospective students can insert contact details and order free brochure (about institution and study programmes) which is delivered to their home address.

Additional analysis revealed some interesting data regarding possibilities for interactive communication on websites and related responsiveness. Namely, the research showed that only 22 institutions or $17 \%$ of the population, offer contact forms ${ }^{11}$ for direct interactive communication with students and other interested parties. Other institutions use more "traditional" way of communication - on the webpage usually entitled

\footnotetext{
${ }^{11}$ Text box on the web site in which interested individuals insert message/query and directly send to person responsible for answering or redirecting querries. Contact form include more or less additional smaller boxes where web site visitors insert contact details, so they can receive answers to email account inbox.
}

Contact visitors can find telephone and email contact information for relevant offices or persons. Related to this, one more analysis was done - checking responsiveness of HEIs. "Neutral"12 query was sent to all 131 institutions - where possible, via contact form, otherwise to email contacts. Only 34 replies were gained, so $26 \%$ of the institutions can be characterized as responsive. Nearly half of those institutions (47\%) replied in period less than one working day, but, on the other hand, nearly one third (29\%) replied after more than a month! ${ }^{13}$

In the end, it is interesting to point out that word of mouth as a form of communications was mentioned only in one case, of a website of one private institution from the field of humanities: " $n \%$ of students enrolled to our institution based on recommendation".

\section{CONCLUDING REMARKS}

Even though the research presented in this paper has certain mentioned limitations (the most important being that only data analysed are those presented on websites as research sources), it stills provides some important and relevant implications for practitioners and researchers from the field of higher education marketing. Indications or concluding remarks, and directions for further research, are presented as answers to research questions that refer to means and types of marketing communications used by HEIs in Serbia.

The most frequently used type is Internet marketing communications. The assumption is that the main reason for this is the cost effectiveness of this type of communications and the fact that actual and prospec-

\footnotetext{
12"Dear Madam/Sir, I would like to ask you if students of other faculties can borrow the books from your institution. Thanks in advance. Yours sincerely..."

${ }^{13}$ Period needed for response from one institution was 35 days, which was the absolute extreme.
} 
tive students prefer Internet as source of information. But, these assumptions need to be tested through further research. The research results showed that most frequently used means of Internet communications are web sites (which are obligatory), facebook, YouTube and twitter. They are more used on state-founded then on private HEIs, most on HEIs from the field of humanities and surprisingly - the least on technical-technological HEIs. Still, issues related to content and regular updates of web sites and other means of Internet marketing communications need to be further investigated.

Advertising is the next most frequently used type of marketing communications, used by two thirds of HEIs in Serbia - equally by public and private institutions. Almost all HEIs from the fields of humanities use advertising, which is much more that other HEIs - those from the fields of technology and medicine use it the least. Most frequently used means of advertising are videos and brochures about institutions, while virtual tours through HEIs are only relatively innovative means.

One third of HEIs in Serbia take part in special events, and one forth of them organize those events. Typical example of events organized by HEIs is Open Doors Day and organized by others - Education Fair. Organization of special events is more typical for state-founded then private HEIs and those from the field of humanities then other fields. There is no difference between public and private HEIs when it comes to participation in special events, while institutions from humanities and technology participate more than other HEIs. The only relative innovation noted here is Open Doors Day organized more frequently (once a week in the longer period, not only period that directly precedes the enrolment) or open for not only prospective students but also their parents and teachers. Recommendation for the HEIs managers is to make sure that they regularly update websites with information about special events, so that potential visitors can learn about them and feel invited.

Sales promotions are used by only one forth of HEIs, much more on private than public institutions, as their survival depends on sales. All means deployed are very alike, only innovations are "discounts" for early bird applications and presents as "recorded lectures". It is important to note one problem here - some institutions present benefits that all students in Serbia have because of their status, as exclusive benefits that only students from those institutions have, which is deceptive.

According to the information on HEIs' websites, PR is present on nearly one tenth of them, but only cases when contact of PR persons/services was explicitly mentioned were taken into account. Suggestion for HEIs management is, therefore, to clearly present on website who is a person/service working in PR in organizational scheme and in the part with contact information on websites. The same applies to publicity - research results show that less than one tenth of institutions have publicity, so managers obviously need to monitor these media reports better, to record and upload them regularly.

Direct marketing communications activities are the rarest, which is problematic having in mind the importance of relationship marketing on HEIs. The only presented information about personal selling refers to presentations in targeted high schools which is done by almost all HEIs, but presented on the website of only one. Potential innovative activity in this field is one mentioned workshop for pupils with simulation of student experience for a day. Research of direct marketing as a type of communications showed that HEIs need to strengthen possibilities for interactive communication with students and others and to significantly increase responsiveness.

Final conclusion is that, although HEIs use numerous types and means of marketing communications, innovative and creative activities are scarce. Integration of used means and types is necessary, so unique, consistent message can be sent to students and public and avoid misunderstandings and confusion. Integration of other means and types with Internet is crucial as students prefer it as a source of relevant information. 


\section{References:}

1. Bakewell, C. J. \& Gibson-Sweet, M. F. (1998). Strategic Marketing in a Changing Environment: are the new UK universities in danger of being "stuck in the middle"? The International Journal of Educational Management, 12 (3), 103-107.

2. Baldwin, G. \& James, R. (2000). The market in Australian HE and the concept of the student as an informed customer. Journal of Higher Education Policy and Management, 22 (2), 139-148.

3. Cohen, G. \& Harris, L. (2003). Marketing in the Internet age: what can we learn from the past? Management Decision, 41 (9), 944-956.

4. Davies, P. \& Scribbins, K. (1985). Marketing Further and Higher Education. York: Longman Group Ltd.

5. Doyle, P. \& Lynch, J. (1979). A strategic model for university planning. Journalof the Operational Research Society, 30 (7), 603-609.

6. Edmiston, D. (2008). An examination of integrated marketing communication in US public institutions of higher education. International Journal of Educational Advancement (8), 152-175.

7. Gatfield, T., Barker, M. \& Graham, P. (1999). Measuring communication impact for university advertising materials,.Corporate Communications: $A n$ international Journal, 4, 73-79.

8. Gibbs, P. \& Knapp, M. (2001). Marketing Higher and Further Education: An Educator's Guide to Promoting Courses, Departments and Institutions. London: Kogan Page.

9. Grubor, A. (2012). Izazovi kvaliteta usluga visokoobrazovnih institucija. Ekonomske teme, 50 (4), 615-631.

10. Hemsley-Brown, J. \& Oplatka, I. (2006). Universities in a competitive global marketplace. International Journal of Public Sector Management, 19 (4) , 316-338.

11. Hesketh, A. J.\& Knight, P. T. (1999). Postgraduates choice of programme: helping universities to market and postgraduates to choose. Studies in Higher Education, 24 (2), 151-163.

12. Hunt, S. D. (1976). The Nature and Scope of Marketing. Journal of Marketing, 40 (July), 17-28.

13. Ivy, J. (2001). Higher Education institution image: a correspondence analysis approach. The International Journal of Educational Management, 15 (6), 276-282.

14. Keen, C. \& Warner, D. (1989). Visual \& Corporate Identity: A study of identity programmes in the college, polytechnic and university environment. Leeds: Heist Publications.

15. Keith, R. (1960). The marketing revolution. Journal of Marketing, 24 (1), 35-38.
16. Komisija za akreditaciju i proveru kvaliteta. (2014). Vodič kroz akreditovane studijske programe na visokoškolskim ustanovama u RS. Dopsupno na: http://www.kasss.rs/wpcontent/uploads/2014/07/ Водич-кроз-акредитоване-студијске-програмена-високошколским-установама-у-РепублициСрбији.pdf pristupljeno: 22.7.2014.

17. Kotler, P. (1979). Strategies for introducing marketing into nonprofit organizations. Journal of Marketing, 43 (1), 37-44.

18. Kotler, P. \& Fox, K. F. (1985). Strategic Marketing for Educational Institutions. New Jersey: Prentice-Hall.

19. Kotler, P. \& Keller, K. (2006). Marketing menadžment, prevod 12. izdanja.Beograd: Data status.

20. Kotler, P. \& Levy, S. J. (1969). Broadening the Concept of Marketing. Journal of Marketing, 33 (January), 10 15.

21. Mainardes, E. W., Alves, H. \& Domingues, M. J. (2010). The attraction of students in undergroduate course in management: Multycase study on the factors attracting students in Joinville. International Journal of Business Strategy, 10 (1), 115-126.

22. Maringe, F. (2005). Interrogating the crisis in higher education marketing: the CORD model. International Journal of Educational management, 19 (7), 564-578.

23. Mortimer, K. (1997). Recruiting overseas undergraduate students: are their information requirements being satisfied? Higher Education Quarterly, 51 (3), 225-238.

24. Nacionalni savet za visoko obrazovanje. (2006). Pravlnik o standardima za samovrednovanje $i$ ocenjivanje kvaliteta visokoškolskih ustanova [Rules and Regulations on Self-assessment and Quality Review of Higher 658 Education Institutions], dostpuno na: http://www.kapk.org/images/stories/ pravilnici/prilog6.pdf, pristupljeno: 4.2.2015.

25. Naude, P., Ivy, J. (1999). The marketing strategies of universities in the United Kingdom. The International Journal of Educational Management, 13 (3), 126-134.

26. Niculescu, L. (2009). Applying marketing to higher education: scope and limits. Management \& Marketing, 4 (2), 35-44.

27. Odbor za akreditaciju naučno-istraživačkih organizacija Ministarstva prosvete, nauke i tehnološkog razvoja Republike Srbije (2014). Spisak akreditovanih fakulteta i univerziteta, available at: http://www.mpn.gov.rs/images/content/akreditacija NIO/Akreditovani_fakulteti_i_univerziteti-2014_02. pdf, retrieved on January 27, 2015. 
28. Oplatka, I. (2002). Implicit contradictions in public messages of ,low-stratified' HE institutions: the case of Israeli teacher training colleges. The International Journal of Educational Management, 16 (5), 248-256.

29. Popović, A. (2010). Direktni marketing u neprofitnim organizacijama. Marketing, 41 (3) , 179-194.

30. Popović, A., Stanković, Lj., Đukić, S. (2015), Positioning Strategies of Higher Education Institutions in the Republic of Serbia. Teme, XXXIX (3), 643-659.

31. Russell, M. (2005). Marketing education: A review of service quality perceptions among international students. International Journal of Contemporary Hospitality Management, 17 (1), 65-77.

32. Sander, P., Stevenson, K., King, M., Coates, D. (2000). University students' expectations of teaching. Studies in Higher Education, 25 (3), 309-323.

33. Schüller, D., Rašticová M. (2011). Marketing Communications Mix of Universities Communication With Students in an Increasing Competitive University Environment. Journal of Competitiveness (3/2011), 58-71.

34. Schultz, D. E. (2010) New, Newer, Newest, Evolving strages of IMC. Journal of Integrated Marketing Communications, 14-21.
35. Stanković, Lj., Đukić, S. (2014). Marketing komuniciranje. Ekonomski fakultet Univerziteta u Nišu.

36. Stanković, Lj., Popović, A. (2014). Propagandni apeli visokoškolskih ustanova: kako privući buduće studente? Antikrizne politike i postkrizni procesi: Изазови Izazovi ekonomske nauke (redaktori: Z. Aranđelović, S. Marinković), str. 523-537. Економски Ekonomski fakultet Univerziteta u Nišu.

37. Tam, F. (2007). Rethinking Schol and Community Relations in Hong Kong. Journal of Educational Menagement, 21 (4), 350-366.

38. Tapper, E., \& Salter, B. (1995). The changing idea of university autonomy. Studies in Higher Education, 20 (1), 59-71.

39. Temple, P. \& Shattock, M. (2007). What does „Branding” mean in higher education? In: Stensaker B. and D'Andrea V. (eds.) Branding in Higher Education, Exploring an Emerging Phenomenon. (pp. 73-82). EAIR Series Research, Policy and Practice in Higher Education.

40. Zakon o visokom obrazovanju Republike Srbije (2013), „Službeni glasnik RS“ br. 76/2005, 100/2007 - autentično tumačenje, 97/2008, 44/2010, 93/2012 i 89/2013: http://www.paragraf.rs/propisi/zakon_o_ visokom_obrazovanju.html, pristupljeno: 22.03.2015.

\section{Apstrakt:}

\section{Marketing komuniciranje visokoškolskih ustanova u Republici Srbiji}

\author{
Ana Popović
}

U cilju suočavanja sa povećanom konkurencijom i ostalim izazovima na tržištu, visokoškolske ustanove (VŠU) su počele da primenjuju nove poslovne pristupe, što je dovelo do razvoja menadžmenta i marketinga visokoškolskog obrazovanja. Efikasno marketing komuniciranje je neophodno za dostizanje ciljeva vezanih za opstanak i razvoj na tržištu, pa teme iz ove oblasti imaju značajno mesto u marketingu visokoškolskog obrazovanja još od uspostavljanja te discipline. Različite strategije, aktivnosti, oblici i sredstva marketing komuniciranja definisani su u teoriji. Savremene tendencije podrazumevaju njihovo integrisanje u cilju ostvarivanja komunikacionih i strategijskih ciljeva organizacije.
Nakon pregleda specifičnosti marketing komuniciranja u pomenutom kontekstu, opisano je realizovano empirijsko istraživanje koje se odnosi na VŠU u Republici Srbiji. Polazeći od činjenica da se tržište visokoškolskog obrazovanja u Srbiji primetno proširilo relativno nedavno i da se konkurencija značajno povećava od 2000. godine, u glavnoj hipotezi je izneta pretpostavka da VŠU u Srbiji koriste brojne aktivnosti marketing komuniciranja. Glavno istraživačko pitanje je: Koji oblici i koja sredstva marketing komuniciranja se koriste i do koje mere su integrisani? Istraživanje je zasnovano na veb sajtovima VŠU kao glavnom izvoru informacija, jer su oni zakonski obavezujuće sredstvo komuniciranja za VŠU u Srbiji. Au- 


\section{marketing}

tor traga za ostalim oblicima i sredstvima komuniciranja koji su integrisani, ili bar pomenuti na veb sajtovima, i tretira to kao indikacije integrisanog marketing komunciranja. Glavni nalazi istraživanja potvrđuju pretpostavku o korišćenju raznih sredstava i oblika marketing komuniciranja, ali otkrivaju i probleme u njihovoj integraciji i ukazuju na to da većina ustanova koristi slične aktivnosti, kao i da su inovativni i originalni oblici i sredstva veoma retki.

Ključne reči: visokoškolske ustanove, marketing komuncirianje, konkurencija, konkurenska prednost, integrisano marketing komuniciranje, marketing visokoškolskog obrazovanja

\section{Kontakt:}

M.Sc. Ana Popović, asistent ana.popovic@eknfak.ni.ac.rs

Ekonomski fakultet Univerziteta u Nišu

Trg K.A. Ujedinitelja 11, Niš 